\title{
Mediating in intercultural communicative challenges issued in the language classroom: a new objective in training programs for new teachers
}

\author{
Gabriel Sanchez-Sanchez ${ }^{1} \&$ Marek Krawiec ${ }^{2}$ \\ ${ }^{1}$ Universidad de Murcia, Spain \\ ${ }^{2}$ Wielkopolska University of Social and Economic Studies, Środa Wielkopolska \\ gsanchezsanchez@um.es, marass24@wp.p1
}

\begin{abstract}
Gabriel Sanchez-Sanchez \& Marek Krawiec. Mediating in intercultural communicative challenges issued in the language classroom: a new objective in training programs for new teachers. Poznan Society for the Advancement of Arts and Sciences, PL ISSN 0079-4740, pp. 95-105

The Faculty of Education Universidad de Murcia (Spain) offers a four-year degree programme in primary education, where modules and subjects related to the foreign language (English) are taught in the first, third and fourth years (OJE 2010). The current teacher training programmes should take into account the most recent political events in Europe so that they can be adjusted to suit the Council of Europe's original linguistic and cultural education policy. This article will explore intrinsic aspects of foreign language and culture teaching, and the learning process, in relation to communication and understanding among all European citizens. This analysis will help to identify the implications of 21 st-century education policy in terms of the skills of newly-qualified teachers.
\end{abstract}

Keywords: acculturation, culture, education, intercultural competence, teacher training

\section{Introduction}

Vygotsky (1995) claimed that the origin of language was social and that it influenced human thought. Therefore, he added, the origin of thought had to be equally social. It is the social nature of language and thought that encourages us to think of languages as a variety of visions of the world particular to each human society.

To describe rain that falls with force and resoundingly, in Spanish we use the expression 'to rain to pitchers' ('llover a cántaros'), in English, the expression 'to rain cats and dogs' and in French, the expression 'pleuvoir des cordes' ('to rain ropes'). These types of idiomatic expressions corroborate the theory that identifies languages with particular perspectives of the world. Notwithstanding being semantically disparate, they all denote a meteorological phenomenon unique in the physical world. 
In general, these types of idiomatic expressions respond to two specific characteristics in relation to their meaning and their usage. On the one hand, their meanings are not compositional, that is, they do not derive from individual components, but rather from their meaning as a whole. On the other hand, they respond to the exclusive uses and customs of the geographical places in which they are used.

This leads us to the question how they get incorporated into the linguistic repertoire of individuals and how understanding occurs. Through an immersion process that takes place within the social environment to which he or she belongs, the social individual inherits, gives meaning to and uses all the information that determines his or her cultural dimension through language, contributing in this way to the perpetuation of an exclusive vision of the world (Miranda 2016).

The purpose of this paper is to examine how language and culture work so that the foreign language teaching and learning process can be improved. The paper concentrates on the aspects related to the initial stages of the foreign language acquisition process. Describing foreign language acquisition in a school setting usually involves examining, for example, the context in which the language is presented, skill developing tasks, the learner's attitude - and their implications for the teacher. After determining whether or not a specific group of student-teachers has acquired the essential skills that their future professional role involves, this paper will suggest ways to improve a specific teacher training programme.

\section{Language, culture and education}

It is important to bear in mind that there is a close relationship between the two key concepts which were introduced at the beginning of this article. Language has been identified as a cultural product and culture, in turn, needs language both for its expansion and its consolidation (Claxton 2006). Through language, a human group rooted in a specific geographical area transmits to its new members all the information necessary for them to gain their ethnic group identity (enculturation) (Aguirre 1993). The idiomatic expressions referred to above are a small sample of all that group information which imparts a set of socially transmitted behavioural patterns, knowledge, values, beliefs, attitudes, interactions with others, arts, products, and thoughts (Orange 2008: 63). For the purpose of this work, this is the most appropriate definition of the concept of culture, as all this information seems to justify the fact that the world around us is perceived and experienced in the most heterogeneous ways. In an attempt to promote personal and professional communication and interaction among member states, the Council of Europe finds it important that citizens acquire one another's languages. These are promoted not only as a method for Europeans to understand one another, but also as a way to fight against prejudices and discrimination (Council of Europe 2002: 2). Inspired by this stance on modern foreign languages (FL), local education authorities generally feel that primary education should be then regarded as the framework in which the initial contact with the FL and foreign culture (FC) is to take place (OJRM 2014: 33232). The curriculum of primary education aims for foreign language teaching and learning in context. The 
goal is to train learners to become capable of communicating with other individuals from different cultural backgrounds and from other realities (OJRM 2014: 33230). They should acquire the necessary skills to appreciate and share other visions of the world, thus increasing their possibilities for professional and personal growth. In so doing, learners' value will not be measured only through school achievement but through the development of strategies for dealing with life beyond school (Méndez \& Peña 2013). An education geared towards the success of communication and understanding, and the fight against prejudice and discrimination in Europe, must be based on the acquisition of communicative and intercultural competence. The following sections will examine the cultural dimension of foreign language teaching in primary education and determine its implications for teacher-training programmes in Europe.

\section{The intercultural aspect of the foreign language teaching and learning process}

Authors such as Michael Byram (2003) claim that the ability of being "intercultural" involves affective, cognitive and behavioural elements. Intercultural competence is described as the sum of some attitudes (savoir étre), some knowledge (savoirs), some skills of interpreting and relating (savoir comprendre), some skills of discovery and interaction (savoir apprendre/faire) and some critical cultural awareness (savoir s'engager). These attitudes include respect (valuing the FC), openness (avoiding judgement by deconstructing preconceived cultural assumptions (Moreno-López et al. 2017), curiosity (perceiving differences as learning opportunities) and discovery (tolerance for ambiguity). Sociocultural knowledge comprises knowledge of the ideas, beliefs, customs, values, social behaviours and material artefacts generationally handed down within a particular society (Scott 2014; Colman 2015). It can be grouped within several main categories such as everyday living, living conditions, interpersonal relations, values, beliefs and attitudes, body language, social conventions and ritual behaviour (Council of Europe 2001: 102). The skills of interpretation and relating refer to the ability to interpret a specific document or event from the target culture and relate it to events or documents from the individual's home culture. Discovery and interaction skills are related to the ability to acquire new knowledge about a foreign society, its products and cultural ways of acting; and the ability to manage knowledge, attitudes and skills under the restrictions of real-time communication and interaction. Critical cultural awareness is the ability to evaluate, critically and from explicit principles, perspectives, ways of acting and products in one's own culture and in the culture and country where the target language is spoken (Byram 2003). As mentioned before, primary education is to be regarded as the framework where young learners come in contact with the foreign language and culture for the first time (OJRM 2014: 33232). At this initial stage, the constituent elements of intercultural competence that may play the most significant part in the teaching and learning of the FC are those of knowledge and attitudes. In the next section, we will deal with the physical context in which this initial contact is to take place and in which the learner will be expected to employ all the necessary attitudes. 


\section{FC teaching and learning in context}

Framing the FC acquisition procedure within the physical boundaries of the primary education classroom comes as a result of the analysis of the variety of uses this classroom offers. As the starting point for the long and sometimes tedious FC learning process, the classroom is deemed to be the setting in which the target culture's members' behavioural patterns, values and beliefs are presented to and assimilated by the new learner. Unlike the native speaker of the language, he or she will not acquire this sociocultural knowledge by means of engaging in continual social interaction with other active members of the target culture (enculturation). The context of the classroom should allow the learner to be exposed to the target culture and subsequently, experience a run-through of an intercultural contact by means of an acculturation process (Aguirre 1993; Pérez 2011; Holloway-Friesen 2016). Educational authorities claim that it is absolutely necessary for the teaching of foreign languages to be oriented towards the needs of the learners, who will be expected to express their ideas in the foreign language and subsequently develop their communicative and intercultural skills (OJRM 2014: 33231). With time, the classroom should become a setting where real-life communicative situations are recreated, motivating learners to apply all the sociocultural input they have ac-quired up to a certain moment in their learning process (OJRM 2014: 33276). Learning should derive from the successful resolution of minor intercultural conflicts (Pérez 2011). These fictitious culture practice-oriented situations will constitute a rather limited and controlled sample of what has been known as intercultural communication encounters.

\subsection{Acting interculturally}

As previously stated, learners need to learn the dynamics and acquire the values and norms which are appropriate in the target culture and to apply these appropriately in real-life communicative exchanges with native speakers. In those situations, dialogue is considered a universal tool for communicating and exchanging points of view (Hidalgo 2016). In order to become culturally fluent, learners will have to embrace their vision of the world. The classroom is deemed to be the artificially controlled physical setting for the re-enactment of these initial meaningful communicative contacts, by means of which they will familiarize themselves with the foreign social and cultural milieu. The intercultural communicative encounter (Rodrigo 1999: 19) has also been described as an exposure situation (Ruíz Coloma 2003: 82), as the context of social interaction (García-Rincón de Castro 2006: 47) and as a linguistically and culturally significant experience (European Language Portfolio (ELP) (Council of Europe 2002). Unlike real-life communicative exchanges, the re-enactment of the intercultural communication encounter in the classroom will involve two characters: the learner, and the educator as the source of knowledge about the target culture. The subsection below will focus on the learner's attitude to members of this culture, and to communicative exchanges with them. 


\subsection{Learners ${ }^{6}$ attitude towards the native speakers}

Language learners can display any of the following attitudes to individuals enculturated elsewhere (distinction of attitudes established by the authors, G.S.S. \& M.K.). These attitudes may be held by members of a European state toward other people from elsewhere in Europe, during a communicative exchange:

- Negative attitude: Conditioned by stereotypical information in general, or derived from previous, unsuccessful communicative experiences between the learner and the native speakers of the target language. Respect, openness, curiosity, etc. are virtually non-existent.

- Optimistic attitude: This rather optimistic vision arises from the false belief that the native speaker will interpret and assess the situation, and the learner's performance, from the point of view of the cultural system of the learner.

- Analytic attitude: The performance of the native speaker is meticulously analysed. The learner becomes aware of the norms, values, beliefs, etc., on which the native speakers' performance is based. Nevertheless, he or she is still unable to emulate them, let alone empathize with them.

- Camaraderie attitude: The learner mistakenly believes that the native speaker will ignore his or her linguistic and cultural deficiencies if his or her demeanour is marked by humour, camaraderie, or exaggerated stereotyped behaviour.

- Distant attitude: The native speaker is perceived as the representative of a cultural system with which the learner neither identifies nor feels any interest in becoming familiar with. They demonstrate a lack of respect or curiosity towards the FC (and FL), which fosters prejudice.

- Bicultural attitude: The process of acculturation of the learner has resulted in a level of respect, openness and curiosity about the target culture that justifies the learner's desire to identify culturally with his or her interlocutors and integrate linguistically and culturally into their social group.

\subsection{Learners' attitude towards the intercultural communication encounter}

The success of the communicative exchange between the learner and FC representatives also depends on the former's feeling or opinion about the communicative interaction process itself, or the cultural and/or linguistic way they approach it. In this sense, the following types of attitudes can be listed (distinction of attitudes established by the authors, G.S.S. \& M.K.):

- Negative attitude: The intercultural communicative encounter is perceived as a potentially conflictive situation due to the cultural and/or linguistic ignorance that the learner effuses, which gives rise to the feeling that no intercultural communication will be established between them.

- Optimistic attitude: The learner demonstrates a complete lack of sociocultural (and/ or linguistic) knowledge. He or she is aware of the fact that the intercultural encounter is ill-fated but they have high hopes because they expect the native speakers' good disposition towards speakers from other cultural backgrounds will guarantee the success of their interaction and their mutual understanding. 
- Deluding attitude: The proximity between the target culture and the mother culture, in the framework of a unified Europe, confuses the learner. He or she engages in intercultural communication with the knowledge of norms, values, beliefs and patterns of behaviour of his or her own culture, while lacking sociocultural knowledge of the target culture.

- Bicultural attitude: The learner has acquired good intercultural competence thanks to the acculturation process in the classroom, and can identify himself or herself with the native speaker of the foreign language. The learner also perceives each mock intercultural communication encounter as an opportunity to put all previously-acquired knowledge into practice. This fictitious intercultural interaction, within the boundaries of the classroom, is also seen as a step closer to his or her integration into the sociocultural milieu where the target language is the official language.

\section{The role of the educator in the intercultural classroom}

The linguistic and cultural policy of the Council of Europe affects two of the most essential elements of the educational process: the classroom and the teacher. The former, as we have seen previously, becomes a controlled context where the initial contact between primary education students and the foreign language and culture will take place. As for the latter, this section will describe the teacher's profile from the point of view of the responsibilities arising from this linguistic and cultural policy.

\subsection{The role of the teacher as facilitator}

The process of learning a foreign language and culture has been described as strenuous, as it demands a great deal of mental effort from the learners (Claxton 2006). As a facilitator, the educator will help them acquire the target culture (and language) more easily.

The curriculum for primary education in the Autonomous Community of the Region of Murcia encourages learners in the last years of primary school to participate in real computer-mediated communication (i.e. skype, telephone) (Luque-Agulló \& Martos-Vallejo 2013). Numerous opportunities to establish real intercultural communication encounters are provided for the learners, resulting in a much smoother transition from simulation to real-life communicative interaction.

\subsection{The role of the teacher as cultural acquisition inspirational model}

Real conversations on the telephone or via skype are suggested as an alternative to real-life interaction, as few members of the FC culture live near most schools. The Common European Framework reminds educators that their actions, a reflection of their attitudes and their capabilities, play a very important part in the learners' acquisition of 
sociocultural knowledge (Council of Europe 2002: 142). It will depend on the teacher whether learners gain things necessary for such acquisition: curiosity, openness, respect and a predisposition to suspend negative views of the target culture. As mentioned before, learners will not, at this initial stage, likely have much chance to socialize with native speakers of the target language. Notwithstanding that disadvantage, the teacher is expected to use his or her knowledge of the target culture and act as a kind of cultural attaché in the primary education classroom (Krawiec 2015; Sánchez-Sánchez 2016).

\subsection{The role of the teacher as mediator}

Those who are used to their own norms, values, beliefs, customs and patterns of behaviour find change disquieting; they may sense a loss of control when people from different cultural backgrounds come together (Punset 2007; Elaldi 2016). Psychotherapists have identified five types of symptomatic manifestations of anxiety: physical, psychological, behavioural, cognitive and social (Ellis 2016). The educator must intervene to help beginner learners deal with initial intercultural communication encounters via telephone or skype. It is of paramount importance to reduce the anxiety generated by the unpredictability of the intercultural situation.

\section{Methodology}

\subsection{Purpose of the study}

Inspired by the information related to FL and FC learning and the learners' attitude towards it, the authors set out to evaluate a group of future teachers' skills. The study's fundamental objective was to discover whether a specific group of students in a teacher-training programme had acquired the essential skills to fulfil the requirements of their future role in the intercultural classroom. The authors sought to answer the following question: Are new teachers in training acquiring enough sociocultural knowledge to behave as cultural acquisition inspirational models and to shape their future primary education pupils' attitude towards FL and FC learning?

\subsection{Context and participants}

The study population consisted of 60 student teachers who were in their final year of the four-year degree programme in Primary Education in the Faculty of Education at the University of Murcia (Spain). By the time the study was conducted (2017-2018), the subjects had already studied the compulsory subjects of 'Oral and written communication in Primary Education" in their first year and 'Teaching and learning English', in their third year. In the fourth and final year of their degree, the subjects had chosen modules leading to obtaining the FL teacher (English) status. Among the participants, there were 
51 female subjects $(85 \%)$ and 9 male subjects $(15 \%)$. The average age of the surveyed students was 21 years.

\subsection{Data collection}

To obtain information on the level of sociocultural knowledge that the students possessed, an open and anonymous questionnaire was prepared as a measurement instrument for data collection. The questionnaire was distributed in class during a single session of one hour. The surveyed subjects were urged to imagine that they were participating in five situations involving communication with those from other cultures. The situations, while fictitious, were very possible in a country where English is spoken (here, the United Kingdom). It was important to prevent them from responding from the point of view of their home culture. Thus their level of knowledge of the customs, values, beliefs, etc., of the target society would be deduced from their answers. The first situation, related to the category of 'living conditions', focused on the subjects' ability to answer a phone call. In the second situation, linked to social conventions, an attempt was made to find out if the students were aware of the importance of punctuality for native speakers of the foreign language. The third one questioned the students' knowledge in relation to interpersonal relationships. It focused on the relationship between the sexes. The fourth situation involved introducing oneself and others. Finally, the last scenario, related again to social conventions, dealt with the importance of queuing in public settings.

\subsection{Data analysis}

The analysis and interpretation of the data collected was carried out with the aim of revealing the trainee teachers' actual level of sociocultural knowledge.

Table 1: Results in the fictitious intercultural communicative situation test

\begin{tabular}{cccc}
\hline \multicolumn{4}{c}{ Frequency $(\%)$} \\
\hline Scenarios & Right answers & Wrong answers & Blank \\
\hline 1 & $3(5 \%)$ & $28(46.6 \%)$ & $29(48.3 \%)$ \\
2 & $10(16.6 \%)$ & $32(53.3 \%)$ & $18(30 \%)$ \\
3 & $5(8.3 \%)$ & $45(75 \%)$ & $10(16.6 \%)$ \\
4 & $8(13.3 \%)$ & $15(25 \%)$ & $37(61.6 \%)$ \\
5 & $49(81.6 \%)$ & $10(16.6 \%)$ & $1(1.6 \%)$ \\
\hline
\end{tabular}

The responses to the first scenario showed that only 5\% of the subjects surveyed would know how to respond to a telephone call appropriately. Regarding the situation in relation to social conventions, only 10 subjects $(16.6 \%)$ were aware of the importance attributed to punctuality in the FC. Only $8.3 \%$ of correct answers obtained in the third 
scenario revealed a clear ignorance of the role played by physical contact, or the absence of it, in interpersonal relationships in the target language country. Similarly, only 8 teachers in training (13.3\%) would be able to introduce themselves and others in sociocultural encounters. Finally, the $81.6 \%$ obtained in the fifth scenario showed that the majority of the surveyed subjects recognized the importance attributed to queuing in social settings.

Table 2: Overall view of answers, frequency and percentages

\begin{tabular}{lcc}
\hline \multicolumn{1}{c}{ Answers } & Frequency & $\%$ \\
\hline Right & 74 & 24.7 \\
Wrong & 130 & 43.4 \\
Blank & 95 & 31.7 \\
Total & 299 & \\
\hline
\end{tabular}

In general, it could be concluded that only $24.7 \%$ of the surveyed students would know how to act properly in the sociocultural environment of the native speakers of English with whom they would engage in intercultural communicative exchanges. A significant number of the responses $(43.4 \%)$ were conditioned by the patterns of behaviour, values, beliefs, etc., typical of their home culture such as more physical contact (kisses, hugs) with acquaintances $(75 \%)$; the use of expressions directly translated from their mother tongue in introducing other people (25\%) and in answering the phone $(46.6 \%)$; and the relative lack of importance that they attach to punctuality (53.3\%), compared to the importance of being on time for a typical native speaker of the foreign language.

\section{Conclusions}

It has been intended in this article to offer an updated and general view of primary education as the initial stage of compulsory education in Spain. An analysis of curriculum documents indicates that educational authorities throughout Europe call for initial contact with the target language and culture to take place in primary school (OJRM 2014). At this opening stage, the goal is to equip learners with the necessary skills to be able to communicate with other European citizens, including native speakers of the target language, and successfully interact with them in everyday life and, as they grow older, work-related situations. Thus, the understanding among Europe's nations, and the cohesion of the continent, will be promoted. This aspiration is where the Council of Europe's education policy is heading in terms of laws and rules that will govern the operation of our education systems in the twenty-first century.

With this target in mind, education authorities point to the acquisition of communicative and intercultural competence in real-life contexts as the best approach to FL and FC teaching and learning in primary education. On the basis of the authors' interest in the cultural side of the process, they analyzed intercultural competence, traditionally described 
as consisting of attitudes, knowledge, skills of interpreting and relating, skills of discovery and interaction and critical cultural awareness (Byram 2003). They then chose attitudes (savoir étre) and knowledge (savoir) as the most suitable elements for the first stage of learners' training in the foreign culture. This approach is a response to the concern that FL and FC learning should prepare pupils for interaction in real-life encounters with native speakers of the target language.

Both sociocultural knowledge and attitudes towards native speakers and intercultural interaction itself can be taught through sustained practice and instruction. In this sense, it has been explained how the classroom provides a setting for simulations of real-life intercultural communication encounters. Taking part in this kind of controlled interaction, learners have the opportunity to reach the culminating point of their foreign language and culture learning process: applying the knowledge they have gained through an acculturation process in the linguistically and culturally artificial context of the classroom, they will grow as individuals with intercultural skills. These skills will help them fight against prejudices and immerse themselves freely, willingly and successfully in other European socio-cultural environments.

The results of the survey at the University of Murcia are disquieting, in that they may suggest that teachers-in-training at such an institution lack socio-cultural knowledge. This serves as a warning that the teacher-training programme is losing sight of the Council of Europe's original linguistic and cultural education policy. On the one hand, future teachers are not being trained to fulfil their role as inspirational and motivational figures in the process by which learners not only acquire knowledge, but develop appropriate attitudes. Further, these teachers in training are not being provided with the skills to help primary school pupils deal successfully with the fear, anxiety and unpredictability created during the transition from simulation in the classroom to real-life communicative interaction with native speakers.

Therefore, certain adjustments in the degree study programme are called for: one should highlight the importance of the teacher in achieving the targets set by European education policies. For this transition to be smooth and successful, the authors of a new study programme should consider providing teachers-in-training with sufficient opportunities to take part and mediate in real-life intercultural communication encounters. This would provide them with a glimpse of possible activities in the classrooms where they will teach, and an understanding of the goals of these activities.

\section{References}

Aguirre, Angel. 1993. Aculturación. In Aguirre Baztán, A. (ed.). Diccionario Temático de Antropología. $2^{\text {a }}$ Edición, 1-6. Barcelona: Macombo, S.A.

Aguirre, Angel. 1993. Enculturación. In Aguirre Baztán, A. (ed.). Diccionario Temático de Antropología. $2^{a}$ Edición, 219-222. Barcelona: Macombo, S.A.

Byram, Michael. 2003. On being 'bicultural' and 'intercultural. In Alred, Geof \& Byram, Michael \& Fleming, Mike (eds.), Intercultural Experience and Education. Clevedon: Multilingual Matters.

Claxon, Guy. 2006. Learning to learn. Bristol: TLO Ltd.

Colman, Andrew. 2015. Oxford Dictionary of Psychology. Oxford: Oxford University Press. 
Council of Europe. 2001. Common European Framework of Reference for Languages. https://coe.int/en/web/ common-european-framework-reference-languages/? (Accessed 2018-06-23.)

Council of Europe. 2002. European Language Portfolio (ELP). https://coe.int/en/web/portfolio. (Accessed 2018-06-23.)

Elaldi, Şenel. 2016. Foreign language anxiety of students studying English language and literature: A sample from Turkey. Educational Research and Reviews 11(6). 219-228.

Ellis, Albert. 2016. How to control your anxiety before it controls you. New York: Citadel Press Inc.

García-Rincón de Castro, César. 2006. Educar la mirada. Madrid: Narcea.

Hidalgo Nieto, Catalina. 2016. Hermenéutica y Argumentación: Aportes para la comprensión del diálogo intercultural. Estudios filológicos 54. 107-130.

Holloway-Freisen, Holly. 2016. Acculturation, Enculturation, Gender, and College Environment on Perceived Career Barriers Among Latino/a College Students. Journal of Career Development. 1-15. https://www. researchgate.net/publication/308486780_Acculturation_Encultura-tion_Gender_and_College_Environment_ on_Perceived_Career_Barriers_Among_Latinoa_College_Students). (Accessed 2018-06-23.)

Krawiec, Marek. 2015. Socio-cultural elements in foreign language teaching and learning and the development of intercultural competences of students: Theoretical considerations. In: Krawiec, Marek (ed.), Current Issues in Foreign Language Teaching and Learning, 164-183. Regensburg: Sprachlit Verlag.

Luque-Agullo, Gloria \& Martos-Vallejo, Navidad. 2013. Emotions as learning enhancers of foreign language learning motivation. Profile 15(1). 109-124.

Mendez Lopez, Mariza G. \& Pena Aguilar, Argelia. 2015. Mobile learning in the foreign language classroom. Huarte de San Juan. Filología y Didáctica de la Lengua 15. 79-103.

Miranda Chacon, Zaray de los Angeles. 2016. La construcción del conocimiento del estudiantado en el contexto de la educación superior. Reflexiones en torno a su naturaleza biológica y social 40(2). 1-11.

Moreno-Lopez, Isabel \& Ramos-Sellman, Aida \& Miranda-Aldaco, Citali \& Gomis Quinto, Maria Teresa. 2017. Transforming ways of enhancing foreign language acquisition in the Spanish classroom: Experiential learning approaches. Foreign Language Annals 50(2). 398-409.

OJE (Official Journal of the Estate). 2010. Resolution of 30th June, enabling the Degree in Primary Education study programme. Official Journal of the Estate 171. Murcia, 15th July 2010.

OJRM (Official Journal of the Region the Murcia). 2014. Decree $n^{\circ} .198 / 2014$, of 5th September, establishing the Primary Education syllabus in the Region of Murcia. Official Journal of the Region of Murcia 206, Murcia, 6th September 2014.

Orange, Carolyn. 2008. 25 mistakes teachers make and how to avoid them. London: SAGE LTD.

Pérez Francés, María José. 2011. Interculturalidad vs aculturación. Pedagogía Magna 11. 393-397.

Punset, Eduardo. 2007. El viaje a la felicidad. Barcelona: Ediciones Destino.

Rodrigo Alsina, Miquel. 1999. Comunicación Intercultural. Barcelona: Anthropos.

Ruiz Coloma, Cristina. 2003. Atrévase a no ser perfecto. Barcelona: Grupo Editorial Random House Mondadori.

Sanchez-Sanchez, Gabriel. 2016. La comunicación, interacción y entendimiento en la Europa multicultural a través de la actualización de los programas de formación del profesorado especialista en lengua extranjera. Educatio Siglo XXI 34(3). 181-198.

Scott, John. 2014. A Dictionary of Sociology. [electronic resource]. Oxford: Oxford University Press.

Vygotsky, Lev. 1995. Pensamiento y lenguaje. Barcelona: Paidós. 